\title{
Sugar, Sugar Phosphate and NADP(H) Levels in Agaricus bisporus Fruit Bodies
}

\author{
By JOHN B. W. HAMMOND \\ Glasshouse Crops Research Institute, Worthing Road, Littlehampton, Sussex, BN16 3PU, UK
}

(Received 11 May 1984; revised 9 September 1984)

Levels of glucose 6-phosphate, fructose 6-phosphate, 6-phosphogluconate, fructose 1,6bisphosphate, trehalose, glucose, fructose, mannitol, NADP and NADPH were determined in Agaricus bisporus fruit body tissues. Of the phosphorylated sugars, glucose 6-phosphate was present in the largest quantity, at approximately $1.5 \mu \mathrm{mol}(\mathrm{g} \text { fresh } \mathrm{wt})^{-1}$. Fructose was detected in larger quantities than in previous investigations. NADP and NADPH levels were found to be in the range $45-200 \mathrm{nmol}(\mathrm{g} \text { fresh } \mathrm{wt})^{-1}$, with NADP/NADPH ratios between 0.58 and 1.66. The anabolic reduction charge showed a negative relationship with mannitol level. Mass action ratios calculated for glucose-6-phosphate dehydrogenase were several orders of magnitude below the reported $k_{\text {eq }}$ for the reaction. The mass action ratio for glucose-6-phosphate dehydrogenase showed a significant correlation with trehalose content over the period of sampling. The results are discussed with reference to possible controls of the pentose phosphate pathway and mannitol synthesis.

\section{INTRODUCTION}

The metabolism of the Agaricus bisporus fruit body is characterized by the accumulation of large amounts of mannitol, whereas only low amounts are found in the mycelium (Hammond \& Nichols, 1976). Mannitol is synthesized in A. bisporus from fructose, the reaction being mediated by mannitol dehydrogenase, using NADPH as cofactor (Edmundowicz \& Wriston, 1963; Ruffner et al., 1978). The NADPH used for mannitol synthesis is produced in the first two steps of the pentose phosphate pathway (Dütsch \& Rast, 1972), which appears to be more active in the sporophore than in the mycelium (Hammond, 1977).

Increase in mannitol synthesis and extracted glucose-6-phosphate dehydrogenase activity also appear to be related to the initiation of fruit body growth in the periodic fruiting of $A$. bisporus (Hammond, 1981). Thus the pentose phosphate pathway and mannitol synthesis appear to play an important part in the fruiting process. As part of an investigation of these pathways, determination of some of the key intermediates involved was undertaken in order to assess the inter-relationship of pathway activities and intermediate and product levels. The results of the study are reported here.

\section{METHODS}

Aguricus bisporus (strain 'Darlington's 649') was grown in compost under normal commercial conditions. Three fruit bodies per day were sampled at stage 2 of their development (buttons; Hammond \& Nichols, 1975) on five sampling days during a three week period. Tissue was taken from the top of the cap of growing fruit bodies after removing the thin surface layer or 'peel'.

$N A D P(H)$ extraction and assay. The extraction procedure was modified from that of Matin \& Gottschal (1976). Tissue (700-800 $\mathrm{mg}$ fresh $\mathrm{wt}$ ) was sliced into preweighed tubes containing $10 \mathrm{ml} 0 \cdot 11 \mathrm{M}-\mathrm{HCl}$ for NADP, or $0 \cdot 11 \mathrm{M}$ -

Abbreriations: ARC, anabolic reduction charge; F6P, fructose 6-phosphate; F1,6bP; fructose 1,6-bisphosphate; G6P, glucose 6-phosphate; G6PD, glucose-6-phosphate dehydrogenase; MAR, mass action ratio; 6PG, 6phosphogluconate. 
$\mathrm{NaOH}$ for NADPH held at approximately $-5^{\circ} \mathrm{C}$ in an ice- $\mathrm{NaCl}$ bath. After re-weighing the tubes for tissue fresh weight determination, the tissue was homogenized and heated in a water bath to $50^{\circ} \mathrm{C}$ for $12 \mathrm{~min}$. The suspension was cooled to $0{ }^{\circ} \mathrm{C}$ in ice and neutralized using $0.77 \mathrm{M}-\mathrm{NaOH}$ or $\mathrm{HCl}$. Tris/maleate buffer $\mathrm{pH} 7.4$ was then added to a final buffer concentration of $0.11 \mathrm{M}$ in $20 \mathrm{ml}$ total volume. The homogenates were centrifuged at $30000 \mathrm{~g}$ for $15 \mathrm{~min}$ at $4^{\circ} \mathrm{C}$ before assay of the supernatants.

The NADP $(\mathrm{H})$ levels were assayed as described by Nisselbaum \& Green (1969) and Fuhrer et al. (1980). The assay mixture included $0.15 \mathrm{ml}$ extract in a total volume of $1.65 \mathrm{ml}$, and contained $12 \mathrm{~mm}$-glucose 6 -phosphate (G6P), $0.24 \mathrm{mg}$ phenazine methosulphate $\mathrm{ml}^{-1}, 0.09 \mathrm{mg}$ 3-(4,5-dimethyl-thiazolyl-2)-2,5-diphenylmonotetrazolium bromide (MTT) $\mathrm{ml}^{-1}$ in $100 \mathrm{mM}$-Tris/maleate buffer $\mathrm{pH} \mathrm{7.4}$. After measuring the rate of increase of absorbance at $556 \mathrm{~nm}\left(A_{1}\right), 1$ unit of glucose-6-phosphate dehydrogenase (G6PD) (Sigma; Baker's Yeast, Type 15) in $15 \mu \mathrm{l}$ of buffer was added and the new rate of increase of absorbance measured $\left(A_{2}\right)$. The assay was calibrated by adding $10 \mu \mathrm{l}$ buffer containing $0.05 \mathrm{nmol}$ NADP to the incubation mixture and measuring the rate of absorbance increase $\left(A_{3}\right)$. The response was linear over the range $0-1.5 \mathrm{nmol}$ NADP(H). The amount of NADP or NADPH present in the extract was calculated using the formula $\left(A_{2}-A_{1}\right) /\left(A_{3}-A_{2}\right) \times 0.05 \mathrm{nmol}$.

Sugar and sugar phosphate extraction. In order to prevent enzymic modification of sugar phosphates and sugars during extraction, the method recommended by Bieleski (1964) for plant material was used. Approximately $1 \mathrm{~g}$ fresh weight of tissue was cut into $2 \mathrm{~mm}$ cubes, weighed and placed in $20 \mathrm{ml}$ extractant (methanol $/ \mathrm{chloroform} / 7 \mathrm{M}$ formic acid, 12:5:3) held just above its freezing point above liquid nitrogen. The time between removal of tissue from the fruit body to placing in extractant was approximately $2 \mathrm{~min}$. The material was then stored at $-20{ }^{\circ} \mathrm{C}$ for $4 \mathrm{~h}$ before homogenization at $0^{\circ} \mathrm{C}$. The residue was washed with 1 vol. $20 \%$ methanol $/ 0 \cdot 2 \mathrm{M}$-formic acid $(1: 1)$. The filtrate and washings were pooled and split into equal parts for sugar and sugar phosphate determinations, and evaporated to dryness at $40^{\circ} \mathrm{C}$ in a rotary evaporator.

Sugar assays. Dried extract was placed over silica gel under vacuum for $48 \mathrm{~h}$ and then trimethylsilyl derivatives of the material made and analysed by GLC as described by Hammond \& Burton (1983), using inositol as an internal standard.

Sugar phosphate assays. Dried extract was dissolved in $5 \mathrm{ml} 100 \mathrm{~mm}$-Tris/maleate buffer $\mathrm{pH} 7 \cdot 4$, and the hexose phosphates determined as described by Bergmeyer (1965), except that the reaction was followed using a spectrofluorimeter with excitation wavelength set at $340 \mathrm{~nm}$ and emission measured at $460 \mathrm{~nm}$. The total increase in fluorescence was measured after each enzyme addition when a steady state had been reached. The system was calibrated by adding known quantities of sugar phosphates at appropriate points. 6-Phosphogluconate (6PG), G6P and fructose 6-phosphate $(\mathrm{F} 6 \mathrm{P})$ were determined sequentially in the same solution. Fructose 1,6bisphosphate (F1,6bP) was assayed separately. The enzymes used were obtained from Sigma.

\section{RESULTS AND DISCUSSION}

The amounts of sugar phosphates, sugars and NADP $(\mathrm{H})$ found in fruit body tissue at five different sample dates are shown in Table 1. The hexose phosphate present at the highest concentration was G6P, the amount being equivalent to approximately $2 \mathrm{~mm}$ when calculated on a whole cell basis. G6P and 6PG amounts varied least over the experimental period, while those of $\mathrm{F} 1,6 \mathrm{bP}$ declined considerably (Table $1 a$ ). The amount of F6P remained relatively stable. The decline in F1,6bP content relative to F6P could be due to a fall in phosphofructokinase activity and hence Embden-Meyerhof pathway flux over the cropping period. Trehalose, mannitol and glucose levels (Table $1 b$ ) were within the ranges previously reported (Hammond \& Nichols, 1976). Fructose was detected in larger quantities than before, possibly due to use in earlier investigations of extraction methods which are slower to inactivate enzymes, leading to conversion of fructose, perhaps to mannitol, during extraction.

NADP and NADPH concentrations, NADP : NADPH ratios and anabolic reduction charge (ARC) values were similar to those reported for other micro-organisms (Table la) (Fuhrer et al., 1980). The ARC is a measure of the proportion of total NADP $(H)$ available for reductive syntheses (Andersen \& van Meyenburg, 1976). The ARC values obtained showed a significant $(P=0.005)$ negative correlation with the mannitol content of the tissue (Fig. 1). Thus the ARC is higher when mannitol content is low. This relationship indicates that although mannitol synthesis may play a significant part in controlling the NADPH level, the rate of mannitol synthesis is under some control other than simple availability of NADPH.

Mannitol synthesis could be controlled at two points : either the hydrolysis of F6P to fructose, or the reduction of fructose to mannitol. The $k_{\text {eq }}$ of glucose-6-phosphatase is about $10^{3} \mathrm{M}$ (Rolleston, 1972); that for fructose-6-phosphatase is probably similar. The total phosphorus 


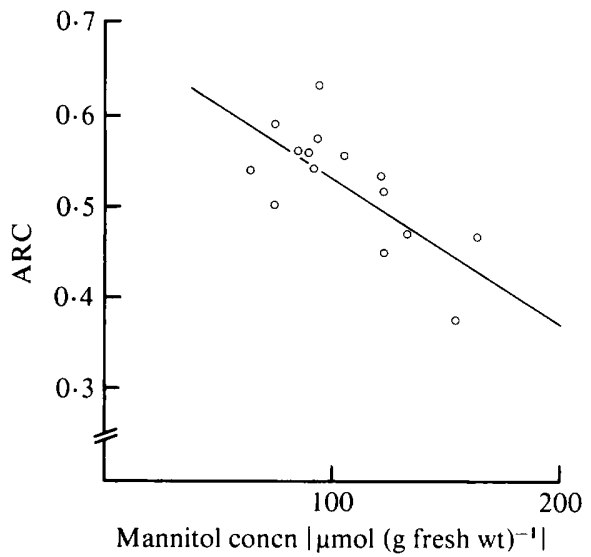

Fig. 1. Scatter plot of ARC vs mannitol levels in fruit body tissue, with regression line drawn in; $r=$ $0 \cdot 705, P=0 \cdot 005$.

\section{Table 1. Concentrations of $(a)$ phosphorylated hexoses and NADP $(H)$ and $(b)$ sugars}

Sporophore caps were sampled at five different times during a crop. Values in nmol ( $\mathrm{g}$ fresh wt $)^{-1}$ and are means of three determinations from separate sporophores, $\pm \mathrm{SE}$.

(a)

$\begin{array}{cccccccc}\text { Sample } & \text { G6P } & \text { 6PG } & \text { F6P } & \text { F1,6bP } & \text { NADP } & \text { NADPH } & \text { ARC } \dagger \\ 1 & 1557 \pm 295 & 39^{*} & 199 \pm 98 & 31 \pm 3 \cdot 9 & 79 \pm 15 \cdot 0 & 71 \pm 12 \cdot 8 & 0 \cdot 47 \\ 2 & 1857 \pm 285 & 48 \pm 5 \cdot 3 & 274 \pm 21 & 27 \pm 2 \cdot 6 & 50 \pm 3 \cdot 4 & 74 \pm 9 \cdot 2 & 0 \cdot 60 \\ 3 & 1623 \pm 244 & 51 \pm 1 \cdot 4 & 289 \pm 53 & 20 \pm 12 \cdot 8 & 123 \pm 24 \cdot 8 & 154 \pm 43 \cdot 2 & 0 \cdot 55 \\ 4 & 1378 \pm 98 & 41 \pm 4 \cdot 5 & 249 \pm 13 & 12 \pm 2 \cdot 4 & 48 \pm 0 \cdot 9 & 56 \pm 7 \cdot 6 & 0 \cdot 54 \\ 5 & 2334 \pm 625 & 38 \pm 7 \cdot 0 & 255 \pm 95 & 9 \pm 3 \cdot 2 & 53 \pm 7 \cdot 4 & 45 \pm 7 \cdot 2 & 0 \cdot 46\end{array}$

\begin{tabular}{|c|c|c|c|c|}
\hline $\begin{array}{l}\text { (b) } \\
\text { Sample }\end{array}$ & $\begin{array}{l}10^{-3} \times \\
\text { Trehalose }\end{array}$ & Glucose & Fructose & $\begin{array}{l}10^{-4} \times \\
\text { Mannitol }\end{array}$ \\
\hline 1 & $11 \cdot 34 \pm 1.7$ & $759 \pm 283$ & $1191 \pm 1259$ & $13.26 \pm 1.9$ \\
\hline 2 & $22 \cdot 23 \pm 4 \cdot 3$ & $804 \pm 813$ & $355 \pm 309$ & $8.58 \pm 0.9$ \\
\hline 3 & $26.77 \pm 14.5$ & $956 \pm 356$ & $3037 \pm 2656$ & $8.32 \pm 1.6$ \\
\hline 4 & $18.02 \pm 2.8$ & $624 \pm 229$ & $691 \pm 475$ & $8.94 \pm 1.6$ \\
\hline 5 & $6.23 \pm 1.7$ & $298 \pm 139$ & $2478 \pm 1681$ & $13.94 \pm 2.0$ \\
\hline
\end{tabular}

* Single determination.

$\dagger$ Anabolic reduction charge, NADPH/(NADP + NADPH).

content of $A$. bisporus fruit bodies is approximately $1.2 \%$ of dry wt. (unpublished). This agrees well with data for other fungi (Beever $\&$ Burns, 1980), and would give a maximal estimate for cell $P_{i}$ concentration of $36 \mathrm{mM}$. Since much of the cell phosphate is in other forms, the true concentration is likely to be much lower. However, using this figure and the fructose and F6P concentrations in Table 1, the mass action ratio (MAR) for fructose-6-phosphatase was calculated to be approximately $0 \cdot 5$. Since the MAR is $3-4$ orders of magnitude lower than the presumed $k_{\text {eq }}$, the reaction is displaced from equilibrium (Rolleston, 1972), and is a possible point of control for mannitol synthesis. This conclusion agrees with previous data obtained in ${ }^{1+} \mathrm{C}$ feeding experiments, which suggested a restriction of the F6P to fructose conversion (Hammond \& Nichols, 1977).

The MAR for mannitol dehydrogenase (Table 2) shows some variation from the reported $k_{\mathrm{eq}}$; however, the difference is not large enough to conclude that the reaction is non-equilibrium in vivo. It is possible that there is some compartmentation of the large quantities of mannitol found in the cell. The effect that this would have on the concentration of mannitol at the mannitol 
Table 2. Mass action ratios $(M A R)$, and reported $k_{\text {eq }}$ values for G6PD (EC 1.1.1.49), mannitol dehydrogenase (EC 1.1.1.138) and phosphoglucose isomerase (EC 5.3.1.9) determined from substrate and product concentrations from Table 1

MAR for mannitol dehydrogenase calculated for $\mathrm{pH} 7 \cdot 0$. MAR values means of three determinations from separate sporophores. Concentrations were calculated assuming that $90 \%$ of fresh wt is cell water (Hammond \& Nichols, 1976). $\mathrm{H}^{+}$concentrations were derived from buffer $\mathrm{pH}$ values.

\begin{tabular}{|c|c|c|}
\hline & $k_{\text {eq }}$ & MAR \\
\hline G6PD + lactonase & $\frac{[6 \mathrm{PG}][\mathrm{NADPH}]}{[\mathrm{G} 6 \mathrm{P}][\mathrm{NADP}]}=\underset{(\text { Gumaa \& McLean, 1969) }}{2.74 \times 10^{4}}$ & $\begin{array}{l}1.85 \times 10^{-2} \\
3.86 \times 10^{-2} \\
3.99 \times 10^{-2} \\
3.45 \times 10^{-2} \\
1.40 \times 10^{-2}\end{array}$ \\
\hline Mannitol dehydrogenase & $\frac{[\text { fructose }][\mathrm{NADPH}]\left[\mathrm{H}^{+}\right]}{[\text {mannitol }][\mathrm{NADP}]}=\underset{(\text { Edmundowicz \& Wriston, 1963) }}{5 \times 10^{-10} \mathrm{M}^{*}}$ & $\begin{array}{l}5.45 \times 10^{-10} \mathrm{M} \\
6.36 \times 10^{-10} \mathrm{M} \\
4.12 \times 10^{-9} \mathrm{M} \\
8.97 \times 10^{-10} \mathrm{M} \\
1.47 \times 10^{-9} \mathrm{M}\end{array}$ \\
\hline Phosphoglucose isomerase & $\frac{[\text { fructose 6-phosphate] }}{\text { [glucose 6-phosphate] }}=\underset{\text { (Gumaa \& McLean, 1969) }}{0.32-0.47}$ & $\begin{array}{l}0 \cdot 13 \\
0 \cdot 15 \\
0 \cdot 18 \\
0 \cdot 18 \\
0 \cdot 11\end{array}$ \\
\hline
\end{tabular}

* Recent determination with pure enzyme gave a value of $2 \times 10^{-11} \mathrm{M}$ (N. Morton, personal communication).

dehydrogenase active site is not clear. Because of this the role of the enzyme in controlling the rate of mannitol synthesis is uncertain.

The probable control step of the pentose phosphate pathway is at G6PD. The MAR calculated for the G6PD + lactonase reaction from the data obtained in this study is about 6 orders of magnitude lower than the reported $k_{\text {eq }}$ (Table 2). This suggests that the reaction is nonequilibrium in vivo, and that the enzyme may be responsible for regulation of the pentose phosphate pathway in $A$. bisporus. In a previous report it was shown that high amounts of extracted G6PD were linked with the initiation of fruit body growth in periodic fruiting of $A$. bisporus (Hammond, 1981). Since the enzyme reaction is non-equilibrium, variations in G6PD activity in vivo will cause variation in pathway flux (Rolleston, 1972), and the observed variations in G6PD activity may be significant in activating the pentose phosphate pathway during the initiation process.

Trehalose also shows maximal concentrations during initiation of a new fruiting phase ('flush'), and its concentration is a good index of the progress of the flush (Hammond, 1981). The MAR for G6PD was significantly correlated with trehalose content of fruit bodies $(r=0.569$; $P=0.05 ; n=14)$. This suggests that the reaction is more active at times when the trehalose concentration is high, and, by inference, when flush initiation occurs. If this is the case, the high activities of extracted G6PD seen at flush initiation are a reflection of increased in vivo activity of the enzyme.

In addition to the control of the G6PD reaction by variations in maximal enzyme activity, there is the possibility of control via substrate concentration. Since the concentration of G6P reported here is well above the $K_{\mathrm{m}}$ of $215 \mu \mathrm{M}$ for $A$. bisporus G6PD (Hammond, 1985), it seems unlikely that variations in this substrate within the range observed would lead to variations in reaction rate. The $[S]_{0.5}$ value for NADP, which shows a sigmoidal saturation curve, is $90 \mu \mathrm{M}$ (Hammond, 1985), and the apparent NADP concentration from Table 1, calculated using fresh wt data, was within the range $50-140 \mu \mathrm{M}$. Variation within this range would cause significant variation in enzyme activity, with more effect at the upper end of the range due to the shape of the saturation curve.

A further possible point of control for hexose catabolism is the phosphoglucose isomerase reaction. In an earlier paper it was reported that this enzyme was susceptible to inhibition by 
6PG, and it was suggested that this could be a mechanism for channelling hexose through the pentose phosphate pathway (Hammond \& Nichols, 1977). The MAR values calculated for this reaction are similar to the $k_{\text {eq }}$ for the reaction (Table 2). Thus the reaction is probably at equilibrium in vivo, and it is unlikely that the enzyme is regulated.

In previous papers, authors have speculated on the role of NADP and NADPH in the control of the pentose phosphate pathway and mannitol metabolism, and the relationship between these two pathways in A. bisporus (Dütsch \& Rast, 1972; Hammond, 1977; Hammond \& Nichols, 1977). The determination of the concentrations of substrates and products of key enzymes of the pathways has allowed an approach to the problem of enzyme activities in vivo to be made. The data reported here suggest that mannitol synthesis reduces the concentration of NADPH in the cell, but that control of mannitol synthesis is exerted at the hydrolysis of F6P. The previously observed variations in extracted G6PD activity appear to be a true reflection of enzyme activity in vivo. Further work on the regulation of the enzymes involved should improve our understanding of the role of the pentose phosphate pathway and mannitol synthesis in the fruiting process.

\section{REFERENCES}

Andersen, K. B. \& von Meyenburg, K. (1976). Changes of nicotinamide adenine dinucleotides and adenylate energy charge as regulatory parameters of the metabolism of Escherichia coli. Journal of Biological Chemistry 252, 4151-4156.

Beever, R. E. \& Burns, D. J. W. (1980). Phosphorus uptake, storage and utilization by fungi. Advances in Botanical Research 8, 127-219.

Bergmeyer, H. U. (1965). Methods of Enzymatic Analysis, 2nd edn. London: Academic Press.

BIELESKI, R. L. (1964). The problem of halting enzyme action when extracting plant tissues. Analytical Biochemistry 9, 431-442.

DütsCh, G. A. \& RAST, D. (1972). Biochemische beziehung zwischen Mannitbildung und Hexosemonophosphatzyklus in Agaricus bisporus. Phytochemistry 11, 2677-2681.

Edmundowicz, J. M. \& Wriston, J. C., JR (1963). Mannitol dehydrogenase from Agaricus campestris. Journal of Biological Chemistry 238, 3539-3541.

Fuhrer, L., Kubicek, C. P. \& Rohr, M. (1980). Pyridine nucleotide levels in Aspergillus niger. Canadian Journal of Microbiology 26, 405-408.

GumaA, K. A. \& MCLean, P. (1969). The pentose phosphate pathway of glucose metabolism. Enzyme profiles and transient and steady-state content of intermediates of alternative pathways of glucose metabolism in Krebs ascites cells. Biochemical Journal 115, 1009-1029.

Hammond, J. B. W. (1977). Carbohydrate metabolism in Agaricus bisporus: oxidative pathways in mycelium and sporophore. Journal of General Microbiology 102, 245-248.

Hammond, J. B. W. (1981). Variations in enzyme activity during periodic fruiting of Agaricus bisporus. New' Phytologist 89, 419-428.

Hammond, J. B. W. (1985). Glucose-6-phosphate dehydrogenase from Agaricus bisporus: purification and properties. Journal of General Microbiology 131, $321-328$.
Hammond, J. B. W. \& Burton, K. S. (1983). Leaf starch metabolism during the growth of pepper (Capsicum annuum) plants. Plant Physiology 73, 61 65.

Hammond, J. B. W. \& Nichols, R. (1975). Changes in respiration and soluble carbohydrates during the post-harvest storage of mushrooms (Agaricus bisporus). Journal of the Science of Food and Agriculture 26, 835-842.

Hammond, J. B. W. \& Nichols, R. (1976). Carbohydrate metabolism in Agaricus bisporus (Lange) Sing. : changes in soluble carbohydrates during growth of mycelium and sporophore. Journal of General Microbiology 93, 309-320.

Hammonmd, J. B. W. \& Nichols, R. (1977). Carbohydrate metabolism in Agaricus bisporus (Lange) Imbach: metabolism of $\left[{ }^{1+} \mathrm{C}\right]$ labelled sugars by sporophores and mycelium. New Phytologist 79, 315325.

Matin, A. \& Gottschal, J. C. (1976). Influence of dilution rate on $\mathrm{NAD}(\mathrm{H})$ and $\mathrm{NADP}(\mathrm{H})$ concentrations and ratios in a Pseudomonas sp. grown in continuous culture. Journal of General Microbiology 94, 333-341.

Nisselbaum, J. S. \& Green, S. (1969). A simple ultramicro method for determination of pyridine nucleotides in tissues. Analytical Biochemistry 27, 212-217.

Rolleston, F. S. (1972). A theoretical background to the use of measured concentrations of intermediates in study of the control of intermediary metabolism. In Current Topics in Cellular Regulation, vol. 5, pp. 47-75. Edited by B. L. Horecker \& E. R. Stadtman. London: Academic Press.

RuffNer, H. P., RAST, D., TOBleR, H. \& KaResch, H. (1978). Purification and properties of mannitol dehydrogenase from Agaricus bisporus sporocarps. Phytochemistry 11, 2677-2681. 